\title{
KONKE்: THE FIRST PUBLIC TRANSPORT IN VILNIUS
}

\author{
Jurgis Vanagas \\ Dept of Urban Design, Vilnius Gediminas Technical University, Lithuania \\ Submitted 26 December 2015; accepted 14 February 2016 \\ first published online 12 April 2016
}

\begin{abstract}
The first public rail transport in the world started functioning in 1820. Like everywhere at that time, horsedrawn coaches heaved on tracks were the most popular. The first horse-drawn tram started carrying passengers in the industrial region of Wales, England. Starting from 1893, three the so called konke lines of such a tram started operating in Vilnius. Although the ticket was expensive to the city residents of those days, however, they intensively used this kind of transport: in 1909, 2.6 million passengers were transported. Although attempts to replace horse drawn-vehicles by internal combustion engines after the First World War were made, this form of transport was found to be irrational and soon gave the way to buses. Initiative for the trams equipped with electric motors was shortly defeated in Vilnius: lack of funds was felt, and confusion in the administration of the city was predominating. For the period 1915-1920, the local government changed very frequently. In 1926, konke tracks were dismantled. Its remains still can be seen at the enclosures of the embankment of the Vilnia (Vilnios upé) confluence. The coaches were sold for suburban residents that erected small cattle-sheds for domestic animals.
\end{abstract}

Keywords: horse-drawn tram; konke; public transport; bus.

\section{Introduction}

Under conditions of a free market economy, the forms of residential construction have dramatically changed: instead of creating large residential districts of the blocks of flats predominant in the post-war decades in Vilnius as well as in other towns of Lithuania, the pace of lowrise housing with gardens has substantially increased. The urban area has spread to outskirts, and the network of streets has expanded.

Compared to the Soviet times, a relative number of cars have substantially risen. Consequently, traffic intensity exceeds their conductivity without the possibility of increasing it in the major part of the streets of the city. The pace of transport service is decreasing (Burinskiene et al. 2011).

For more than a decade, discussions on how to radically improve the public transport system have been held. The proposed scale of suggestions is very wide from improvements in the qualitative indexes of the available transport - shortening journey times, increasing passenger comfort and attempts at making it more attractive to fundamental reforms, including building the lines of above ground (trams) and underground (subway) transport.
Public transport in Vilnius has counted for more than a hundred years.

In the light of inevitable changes, it is worth opening the first pages of its history.

\section{Analytical Part}

The researchers of urban passenger transport make links to the early origins of its first forms that covered long existed transportation of industrial goods and regularly running omnibusses ${ }^{1}$. A stagecoach is supposed to be the earliest type of transport that carried passengers on a regular basis rather than followed non-charter (i.e. booked) routes. Stagecoaches were not rented. At the beginning of the 19th century, the coaches drawn by horses (Fig. 1) were hoisted on iron or steel tracks and called trams ${ }^{2}$. This greatly facilitated the efforts of trac-

\footnotetext{
${ }^{1}$ Omnibus (omnibus the Latin for 'for all') refers to a multiseater passenger-carrying horse-drawn vehicle.

${ }^{2}$ A tram (also known as tramcar; in North America known as streetcar, trolley or trolley car), is a coach that runs on tracks along public urban streets. In the 4th decade of the 19th century, the tram was drawn by horses. Later, electric traction started to be used. Electric current used to reach the motor through a stripper sliding along the wires over the coach.
}

Corresponding author: Jurgis Vanagas 
tion compared with rolling on the pavement of round stones $^{3}$. From about 1852, the tracks of horse-drawn trams were replaced by flange rails rolling on which rubber wheels made coaches non-ear-splitting, silent, easy to use in any weather and under traffic control when the rule of the right (or left) side of the street carriageway was spontaneously followed: the wheels of coaches used to roll steadily from their intended route.

The first horse-drawn crews on tracks started boarding passengers between Oystermouth, Mumbles and Swansea Docks in Wales, UK in 1807 (Fig. 2).

On 26 November 1832, the first horse-drawn trams in Harlem, New York, United States started running. John G. Stephenson from New Rochelle was an American coachbuilder who invented and patented coaches that were produced in his own manufactory and adjusted to the traction of horses or mules.

Horse-drawn trams soon became popular. In the 9th decade of the 19th century, the cities of the US counted 415 tram companies. Tram lines made more than 6 thousand miles, and 188 million passengers were carried out annually.

Horse-drawn trams in the Bleecker Street Line, NY, US were functioning up to 1917, and in Pittsburgh - up to 1923. The last mule-drawn line in Mexico City was dismantled only in 1932, whereas in the Mexican city Celaya, it was functioning even up to 1954.

In 1892, Toronto in Canada was the first city in the New World where horse-drawn passenger coaches were replaced by electric trams.

The first horse-drawn trams in Europe started running between Czech city České Budějovice and Austrian Linz in 1828.

At the moment, horse-drawn trams are functioning as a pleasure ride in a number of city parks worldwide and Disneylands within tourist seasons.

\section{The First Public Transport in Vilnius}

How did Tramvaju street (Tramvaju g.) in Antakalnis district, Vilnius appear if the city has never had the tram, at least the one we can imagine today?

However, it appears that the street is a relic of the horse-drawn tram (konke), heritage from the past that has not left the trace. The old Vilnius plans of the tsarist area called this short lane 'an iron street of horses' (конно-железная городская дорога), because, with reference to one source, at the end of it on the other side of the present V. Grybo street (V. Grybo g.), and according to the other - between Smelio (Smelio g.) and V. Grybo streets, a land plot where the large stables of the socalled konke and coach stands were built stretched. This is the place from which passenger coaches were driven into the present Antakalnio street (Antakalinio g.) and other konke routes.

The horse-drawn tram was functioning in Vilnius for 22 years (Fig. 3). Unfortunately, the city has still been

\footnotetext{
3 The Polish language vividly defines such pavement 'cat's forehead' ('kocie tby').
}

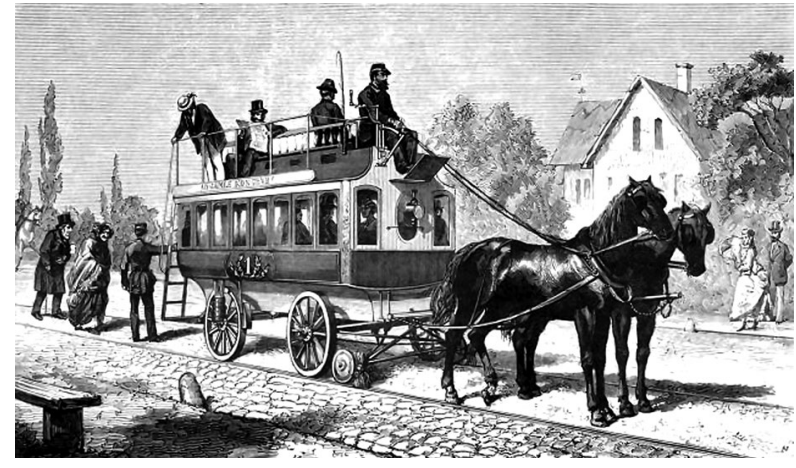

Fig. 1. The first horse-drawn coach (1872) (source: Wikipedia 2015c)

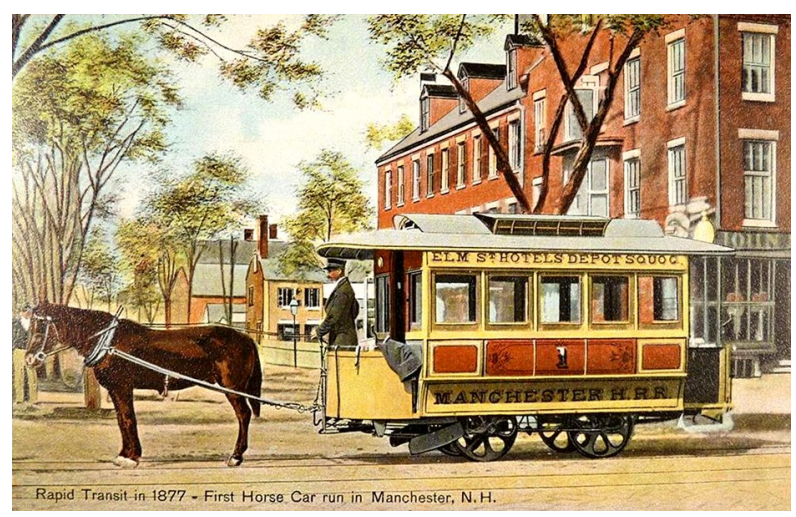

Fig. 2. Horse-drawn tram in Manchester (1877) (source: Wikipedia 2015b)

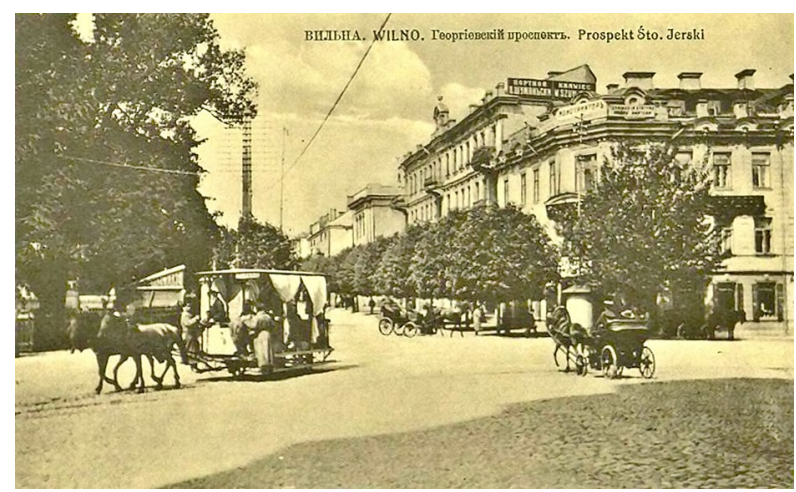

Fig. 3. The konke coach at the beginning of the Georgijevsky prospect (now Gedimino pr.)

(source: Inna Wileńszczyzna jest... 2014)

waiting for the electric tram. Yet in 1823, horse-drawn omnibuses were running in the bumpy streets of Paris (Fig. 4) thus carrying up to 50 passengers (Wikipedia 2015a).

The first horse-drawn tram line started functioning in New York, Harlem on 14 November 1832. On this day, such coaches carrying respectable passengers, including the Mayor of New York and the members of municipality went to the opening route. The new type of urban transport took its roots: following 50 years from opening the first line of it coaches were running in 525 US cities and towns (even in Fort Mide, the smallest of those having only 105 inhabitants). 


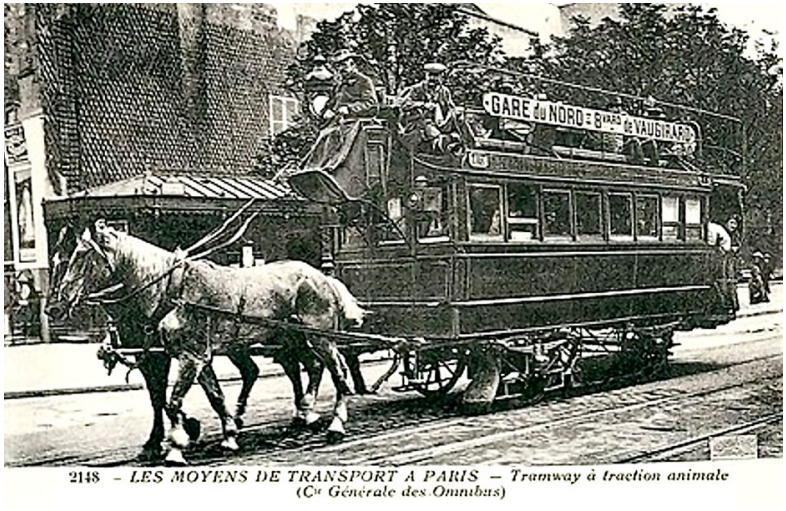

Fig. 4. A horse-drawn tram in Paris (source: Wikipédia 2016)

In 1854, a horse-drawn railway was opened in Paris, and in 1856 - it was established in Berlin and Hamburg. In the 9th decade of the 19th century, similar public transport was available in 18 thousand cities of the US (Wikipedia 2015b).

The first horse-drawn railway in Russia was founded in Nevsky Prospect (Невский проспект), St. Petersburg, in August 1863. 30 years later, on 15 June 1893, a similar railway was set up in Vilnius.

Six years past from proposing an idea to putting it into practice: yet at the beginning of 1887, state advisor engineer A. Gorchakov appealed to the City Duma (Municipal Council) and suggested building the first konke line. The Duma supported the proposal, and, on April 25 of the same year, an appropriate contract was drafted. However, negotiations on the practical implementation of konke were delayed, and only on 25 May 1891, newspaper News of Vilnius Province (Виленские Губернские Hовости) announced the protocol imposed by the Duma on 9 April 1891. The document declared that a Preparatory Commission was set up, and it would be responsible for the final settlement of the issues on building the horse-drawn railway in Vilnius. A. Gorchakov was granted an exclusive right, 'at his own expense and risk' ('на собственный счёт и страх') to construct and operate tracks for carrying passengers and freight along the streets and squares following the directions (Fig. 5):

- from the Green Bridge (Žaliasis tiltas) through Vilnius street to Georgijevsky Prospect (now Gedimino $p r$.) following to Jokūbo side-street and through Uosto and Pylimo streets to Bread Square (Duonos aikštè), and from here to Sodu street and to the square and building of the St. Petersburg-Warsaw railway.

- from the Užupis Bridge (Užupio tiltas) through Alexander Prospect (Avenue), Botany (Botan$i k o s$ g.) street, the Cathedral Square (Katedros aikšte) and, when merged with the first link, to Lukiškès Square (Lukiškiu aikštè).

- from the Cathedral Square through Antakalnio street and Antakalnis suburban area to city limits reaching the Vilija (Neries upé) and the ferry used for city relations with the permanent military camp (Inna Wileńszczyzna jest... 2014).

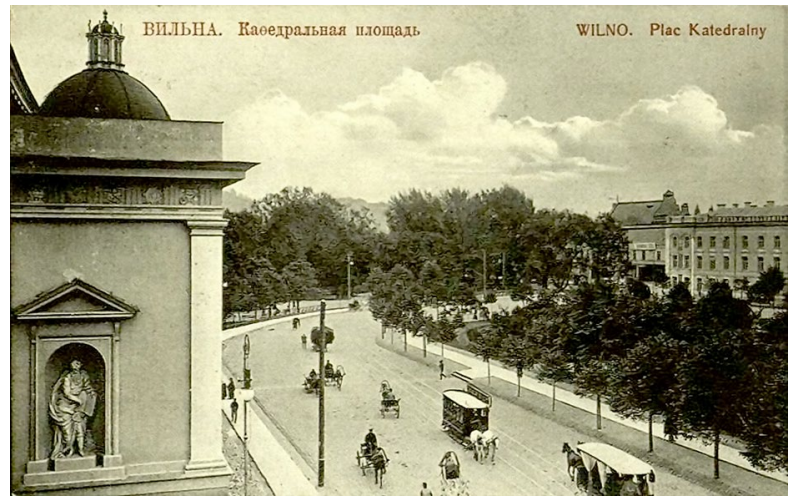

Fig. 5. The konke at the Cathedral Square (source: Inna Wileńszczyzna jest... 2014)

On 16 May 1891, the Vilnius City Duma approved this document, and its chairman secret adviser N. Rubcov handed it to sign to contractor A. Gorchakov.

Tram routes had to operate from 7 a.m. to 10 p.m. It was provided that the coaches would move 12 versts ${ }^{4}$ at a speed of $13 \mathrm{~km}$ per hour. Due to a low width of the street, the route from the Green Bridge to the railway station was decided to be targeted along Gendarme sidestreet (present Jogailos street) and Pylimo street. Only seven years later after the initial proposal, the first konke line the Green Bridge - Railway Station was completed. A. Gorchakov made a few changes in the contract mainly found the need to change the intended width of the horse-drawn railway track from 3.5-4.0 feet to one meter, or 3.28 feet. The railway structure accounted for the steel beams of the flange rail, and coach wheels were originally made of steel and only later replaced by the rubber ones.

In 1892, A. Gorchakov sold his concession to monopoly The Society of Horse Transport in the Russian City and its Suburban Areas (Русское Общество Городского и Пригородного Конского Транспорта). Engineer M. Lachowski who had previously built konke lines in Daugavpils (Latvia), Minsk (Belarus) and Voronezh (Russia) was responsible for constructing the first line.

On 15 June 1893, the opening ceremony of konke took place at the crossroads of Georgijevsky Prospect and Gendarme side-street (present Jogailos street) in Vilnius. After a short speech, Governor General's wife cut the opening ribbon. The family of the Governor General and guests got on the coach and started following the first route. The second coach behind was carrying other important persons of the city.

At the end of June of the same year, the second line the Užupis Bridge - Lukiškès Square, and in July, the third line the Cathedral Square - Antakalnis started functioning. 28 coaches on average made daily trips on three routes.

It was told that two horses heavily drew the konke coach uphill to T. Kosciuškos street, and therefore the

\footnotetext{
${ }^{4}$ Verst - an old Russian measure of length equal to 0.6629 mile, or 1.067 kilometres. Used in Lithuania for the period 1796-1915.
} 
third one was required. A thick branch was leaning over the street from a growing roadside willow at the entrance to the hill park just outside a bridge across the Vilnia. That was the place where a teenager used to sit and put a harness on a horse. When a konke coach used to approach the right place, the chariot used to slow down the two-horse coach, and the teenager deftly, like a cowboy, used to jump off on the coachman's seat, hang the swingletree on the hook, and the coach then was drawn by the troika (тройка). The horses instinctively stopped at the church, the assistant uncoupled his horse, took away the swingletree and trace and rode down to wait for another coach. One or two harnessed horses were drawing the coach approximately at a speed of 13 versts per hour. Seat benches arranged in the transverse direction of the konke coach had a vertical axis. Before taking a seat, at the beginning of the line, passengers had to manually rotate them 180 degrees, because the horse was harnessed to the coach from the other side: the coach was riding back. Such a simplified end of the line dispensed with a turning loop. On 12 May 1893, a resolution on horsedrawn railway operating procedures and rules for passengers was approved by the Board of the City. On 21 June 1893, the resolution was printed by the daily paper News of Vilnius Province. Those were the requirements for the passengers and first public transport in Vilnius:

- any crew using wrong rolling-stock not adapted to tracks is forbidden to ride on the horse-drawn railway;

- the crews and carriages riding on tracks, or in parallel with those, must turn sideways ahead of the coach. For going off the tracks or through them, speed must be reduced; all crews and horse-drawn carriages must give way to the coach, though it is not an exemption from the obligation to stop the coach in case of need;

- dumping and loading debris, mud and snow on the horse-drawn carriageway and tracks, leaving horse-drawn coaches on the rail-carriageway, cluttering or spoiling tracks and dumping debris and mud from the rail-carriageway to other side of the street, sewage ditches and sidewalks are prohibited; also, the horse-drawn railway management team is obliged to supervise the accumulated rubbish and other waste must be raked into piles near the carriageway and taken out of the city to the indicated places at least three times a day; moreover, in order to avoid environmental dust, railway owners are obliged to irrigate the entire carriageway with clean water, as outlined in the resolution issued by the Vilnius City Duma on 25 February 1885;

- if a passenger requests to board the coach and get out of it, the coach must be stopped at any place of the rout except from turn-offs, switches and slopes;

- coach traffic is only allowed at a slow pace at street intersections, driveways from bridges and other slopes as well as in confined spaces and street paving areas;
- horse-drawn railway attendants and escort must be sober, neatly dressed and polite with passengers;

- it is prohibited to board the coach and get out through the front area;

- drunken persons and the passengers wearing severe dirty clothes, for example chimney sweepers, coal handlers, etc. are not allowed into the coach;

- keeping dogs in the coach is prohibited;

- passengers are only allowed to carry with them baggage comfortable to hold; the scope and quality of the carried baggage cannot interfere with neighbours;

- smoking is only allowed in open areas of coaches and open-type coaches;

- in the cases of coach derailment or failure, no refund is provided for the passenger who is only allowed to get into the next coach and continue the journey using the same ticket;

- harnessing stallions is prohibited (Inna Wileńszczyzna jest... 2014).

The class of the seat in Vilnius konke determined the price of the ticket. The 1st class ticket (places in the closed-type coach) cost five kopeks, and that of the 2nd class and in open spaces - three kopecks. The charge was in force from 7 a.m. to 10 p.m., whereas for the rest of the day, the ticket cost was twice more expensive. The children of up to 5 years were transported free of charge in case they did not occupy an additional seat. Those travelling along the first two lines intersecting at Georgijevsky Prospect and Vilnius Street (Vilniaus g.) could acquire the so-called transfer tickets. Thus, if boarded the first-line coach, a passenger was able to transfer in the directions of the Green Bridge or the Railway station.

Vilnius citizens found travelling by konke expensive. Ticket prices were set by a joint stock company combining together horse-drawn railways of Russian cities and suburban areas. The company hold a monopoly in this field, and therefore strictly maintained high tariffs. Neither the discontent of city citizens nor the efforts of Vilnius tycoons to make competition produced positive results. Yet from the very beginning, not all Vilnius residents enthusiastically supported the decision to build horse-drawn railway transport in the city. At that time, newspapers experienced fear that installing tracks on streets might cause accidents. The crews of carriages crossing track lines might find the risk of overturning while the passengers might fall out and experience injury thus jeopardizing their lives. Moreover, the horses of other road users might be frightened by konke coaches, and the passengers that fell out from carriages might face a misfortune of falling under the wheels of the coach.

Despite doubts and protests, konke firmly established itself in the city life.

Soon, it was difficult to accept Vilnius without 'a miracle of the technical progress' of that time. Streets became very lively: coaches produced noise, the chariot continuously rang the bell all the time and screamed thus warning sleeping passers-by. In 1909, 28 coaches 
were running in the city, they were served by $150 \mathrm{em}$ ployees, including chariots and handymen, conductors, controllers, several supervisors, carpenters and painters. That year, konke mileage made 776.3 thousand kilometres and 2.6 million passengers were transported (every city citizen used it on average 14 times). For the period of 15 years of operation, the length of konke lines did not change: similarly like in 1893 , they made more than 9 versts (approximately 10 kilometres).

The Vilnius City Duma constantly interfered in konke work checking it, because the number of complaints and criticism did not decrease in newspapers. In March 1902, the City Council created a special commission responsible for figuring conflicts between urban population and the horse-drawn railway association. The note signed by A. Lapinskis, the chairmen of the commission, found that 12 closed-type coaches from 24 in the horse-drawn railway park required major repair while the rest - permanent one. 13 open-type coaches were operating without permission received from the City Council: the vehicles were not safe for carrying passengers. Strong criticism was addressed to the park due to horses as hauling force. 20 out of 168 horses were quite unsuitable for the job, 34 were too old, 69 horses were improperly fed and therefore diminished, the quality of 37 horses were below the average level and only 8 horses were of fully adequate condition.

The requirement for not harnessing stallions was not satisfied: 93 of those were used in the park. The commission remained unsatisfied with conditions for the waiting rooms of the final stops of the lines. What is more, it seemed that the waiting room of the final stop of Antakalnis line was used as a firewood warehouse rather than according to its direct purpose. A similar situation was observed at the stop of the Užupis Bridge where hay, straw and oats were stored.

Staff clothing did not meet requirements established for konke service providers: it was depreciated and dirty. It turns out that cabmen, conductors and the first horsemen had no funds for buying uniforms. The Commission found significant deficiencies in operating konke. It was established the coaches were always overloaded. The requirement determining that the number of the carried out passengers would not exceed the number of seats was not satisfied. Though regulations required that no more than 2 standing passengers were allowed in the free area at both ends of the coach, a crowd of passengers was usually faced. In addition, the front area was primarily designed for two uniformed policemen having a right to travel free of charge. The full coaches were not achieved to run marked with small red flags on both sides with a note 'All places are occupied'. The konke management team was not honest about selling tickets. All passengers, independently of the class of the coach, were charged the fare of 5 kopeks, which was the price for the 1st class ticket (travelling in the 2nd class, i.e. the fare of the ticket of the transported passengers was only 3 kopecks in the open part of the coach). Even greater lawlessness was established considering the so-called preferential tickets. For the convenience of konke passengers, 100-tickect subscriber books were introduced and offered 30\% (for students - 50\%) discount on the ticket price to passengers. Unfortunately, the book was only valid for exactly one calendar month from the 1st day one of one month to the 1st day of the other. No possibility of using all 100 tickets in a month was observed, and therefore, actually, the owners of the subscriber book were not granted any privilege. Due to the made transgressions, the Commission recommended Vilnius Duma bringing the konke Board to the court. Yet at the initial stage of implementing konke in Vilnius, sceptics were publicly mocking and considered it as an anachronism. The 8th decade of the 19th century was facing the replacement of horse-drawn trams by steam engines worldwide while at the turn of the 19th and the 20 th centuries, they became electrically powered, faster and cleaner. In fact, while granting the concession to A. Gorchakov, Vilnius Duma suggested a possibility of advancing the horse-drawn tram in the future replacing it with steam, electric or internal combustion engines, but failed to take appropriate actions.

Finally, the First World War started, and transport stopped. After the war, the horse-drawn railway was not restored in Vilnius. Only Tramvaju street, formerly called Arkliu geležine (an iron street of horses) (конножелезная городская дорога), in Antakalnis district has survived.

\section{From the Horse-Drawn to Mechanically Driven Tram}

For the period of 20 years, eight projects on an electric tram were designed. The last one was developed before the very beginning of World War I. The line had to connect the centre and suburban areas of the city. It was provided for widening Jogailos street and destroying several secession buildings in Pilies and Arklių streets. Several land lots were purchased, but everything was stopped by the war. Vilnius was occupied by the Germans, the konke depot was destroyed, horses were seized and a part of the tracks were dismantled. The idea of the tram in Vilnius was reborn in the summer of 1924. Engineer L. Piegutkowski installed Ford internal combustion engine in one of the remaining old konke coaches. On 25 July 1924, magazine 'Vilnius Morning' (Wileńskie jutro) printed news, that, yesterday, at 11 o'clock, a tram route from the Cathedral Square to Pospieška was inaugurated. The tram was driven by engineer L. Piegutkowski himself, and all members of the magistrate shared a seat with president Jankowski. And although not all road works were completed, a journey to Pospieška lasted only 18 minutes. The tram stopped twice: because of the jam in the engine and due to coach derailment. The experts were happy and believed that, in case tracks would be properly serviced, the trip to the end of Antakalnis could last no longer than 10 minutes (Fig. 6).

Although not for long but Pigutka routes were opened along the other lines of old konke. The tram coach powered by the internal combustion engine experienced technical problems. 'The tracks of the horsedrawn railway (flange rail) were adjusted to driving at a speed of $5-8 \mathrm{~km}$ per hour, and the mechanical tram 


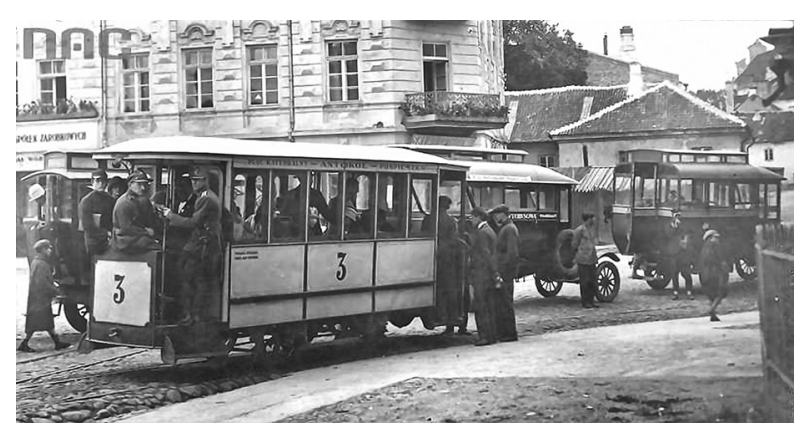

Fig. 6. The konke coach improved by engineer L. Piegutkowski (1924)

(source: Inna Wileńszczyzna jest... 2014)

moved at a speed of $20 \mathrm{~km} /$ hour and even faster, it was not surprising that all passengers used to get off at tram derailment, set the coach on the track and continued their journey'. Moreover, the structure of old konke coaches was weak, the engine constantly broke and fires devastated coaches. Building new coaches was underfunded. More recent buses started successful competition with a far from perfect hybrid of konke and the internal combustion engine. The first Saurer-type buses appeared in Vilnius in the middle of the 3rd decade and were brought from Arbon city. They were simply called 'arbons', and, within the interwar period, this synonym of the bus put down its roots in the colloquial speech of Vilnius citizens.

The first bus route followed from the Cathedral Square to Verkiai.

Similarly to konke, buses were shyly accepted by Vilnius citizens. Yet in 1908, a few proactive businessmen (G. Ščerbakovas, I. Jučas, F. Januševskis, etc.) appealed to Vilnius Duma and suggested opening the first bus lines in the city. Due to the fact that, until then, city transport had been only regulated following rules for cabmen, the local government, before proposing a resolution, were advised by the city boards of St. Petersburg an Kyiv. The law on the compulsory use of cars, the transportation of passengers and cargo destinations in Vilnius was adopted on 24 February 1909 (Žičkus $2014 a)^{5}$. The law permitted driving single-storey buses at the maximum speed of 15 versts per hour and banned riding vehicles on 69 streets of Vilnius city. The busses were allowed running on the previous konke routes only, and the first one had to follow from the Cathedral Square to Antakalnis.

On 18 June 1909, the provisions unusual for these days were included by City Duma into the law. The driver was required to be sober, not to behave rudely with passengers, not to smoke while driving, do not swear, not to sing, not to leave the vehicle unattended, run at a moderate speed, always keep on the right side of the road, not to race, warn slow moving vehicles with the help of audible alarm, overtake only on the left side, shed

5 The researchers of bus transport history in Europe propose that the first bus started running in Germany in 1895. It took 1 hour 20 minutes to pass through the route of 154 kilometres between the cities of Deuz and Siegen (Žičkus 2014a). lights in the dark. Later, travel fares were determined: from Užupis to the Žvèrynas Bridge - 5 kopeks, from the Green Bridge to the Railway Station (вокзал) - 5 kopeks, from the Cathedral to the horse-drawn tram park (present Tramvaju street) - 7 kopeks, from here to Pospieška (the end of Antakalnis district) - another 5 kopeks. At the beginning of 1910, the second bus route Žverynas- the Cathedral Square -Antakalnis was opened.

The same 1910 year, the city owned six registered cars. Nevertheless, vehicle collisions had begun two years ago. The first officially recorded accident caused by the internal combustion engine-driven vehicle occurred in Vilnius on 8 November 1908 (Figs 7-9). Next day, Vilnius newspapers wrote: 'There is one car running along the streets in our city, scaring horses and paying attention of all spectators in the street. No events had happened until yesterday, but that day, about one oclock in the afternoon, driver distraction resulted in a collision. The driver ran into cabman No 617 by the Cathedral, severely injured a horse and broke a coach. A passing-by commissar seized the car and sent it to the police board with a special escort' (Pirmosios avarijos 2005).

In 1926 , following the order issued by the local government, horse-drawn railways in Vilnius were dismantled, and the rest of the coaches were sold to the city residents and turned into cattle sheds used for keeping

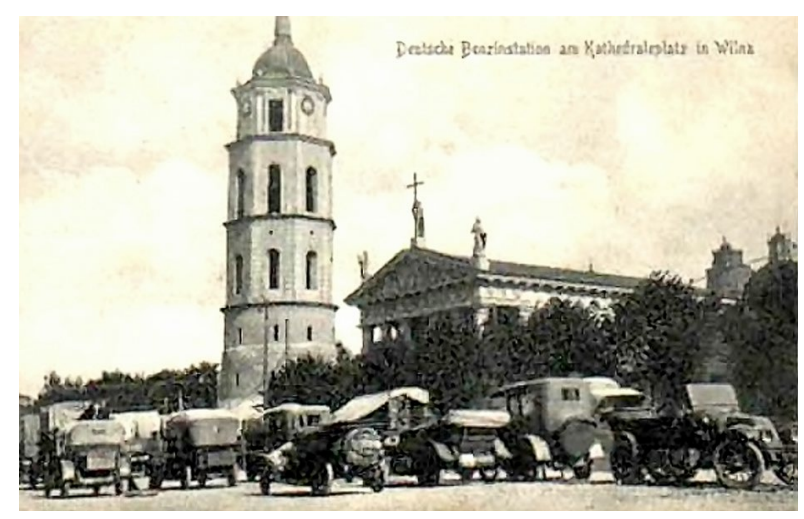

Fig. 7. Cars at the petrol station at the Cathedral (beginning of the 20th century) (source: Made in Vilnius 2014)

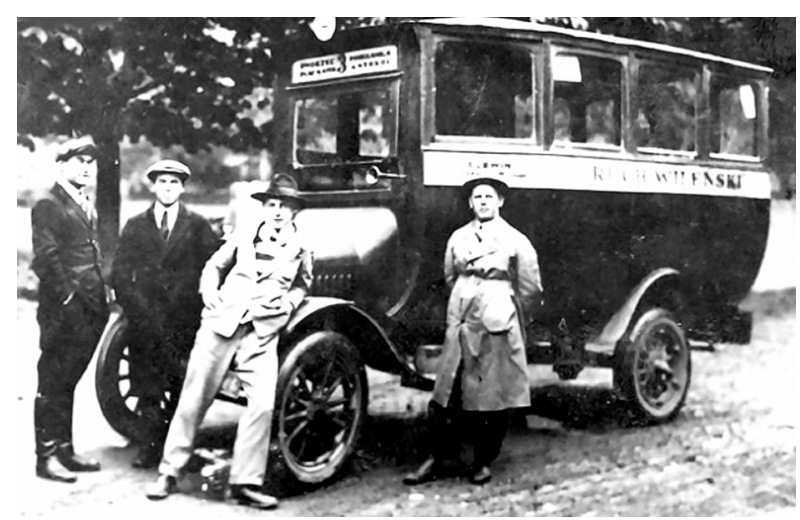

Fig. 8. A bus manufactured by 'Ruch Wileński' (1928) (source: Wilnoteka 2014) 


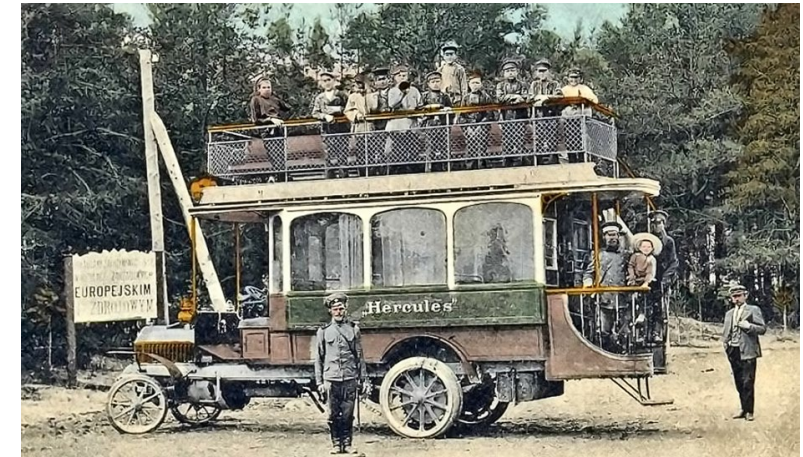

Fig. 9. One of the first buses in Lithuania (Druskininkai, beginning of the 20th century) (source: Žičkus 2014b)

domesticated animals. The remains of konke tracks in Vilnius can be seen at the embankment of the Vilnia confluence: they have been used for building a sidewalk guard from the slope.

\section{Conclusions}

Statistical data suggest that, according to the number of vehicles per 1000 inhabitants (more than 600), Vilnius is ranked very high worldwide (Vilniaus miesto susisiekimo... 2015). This index is alarmingly increasing: population surveys show that public transport is slow, uncomfortable, not punctual, having low prestige and suffering from poor waiting and driving conditions. Growing traffic jams, high air pollution in the streets and therefore experienced losses during the year exceed the city budget by more than one time and a half. All this forces to seek a way out of the encountered situation - a strategy for public transport reconstruction must be cardinally rethought.

The problem of forthcoming public transport in Vilnius still remains unsolved, whereas the origin, evolution and first steps of a more than a century old transport system have been presented in this paper.

\section{References}

Burinskienė, M.; Paliulis, G. M.; Ušpalytė-Vitkūnienè, R.; Grigonis, V.; Juškevičius, P.; Pakalnis, M.; Valeika, V.; Naujokaitis, L.; Jazavitas, J.; Noreika, M.; Lukšas, A.; Barbaza, J. P.; Cerri, V.; Bružienè, V. 2011. Nauju transporto rūšiu diegimo Vilniaus mieste specialusis planas: koncepcija. Vilnius. 153 p. (in Lithuanian).

Inna Wileńszczyzna jest możliwa. 2014. Konka. Available from Internet: http://rojsty.blox.pl/2013/11/8222Konka8221. html (in Polish).

Made in Vilnius. 2014. Katedros aikštè. Available from Internet: http://www.madeinvilnius.com/lt/vilniaus-miesto-studija/ katedros-aikste/i/ (in Lithuanian).

Pirmosios avarijos. 2005. Transporto pasaulis 11(59). Available from Internet: http://www.tp.cargo.lt/content.php?art_ $\mathrm{id}=1312$ (in Lithuanian).

Vilniaus miesto susisiekimo sistema. 2015. Available from Internet: http://www.vilnius.lt (in Lithuanian).
Wikipédia. 2016. Compagnie générale des omnibus. Available from Internet: https://fr.wikipedia.org/wiki/Compagnie_ g\%C3\%A9n\%C3\%A9rale_des_omnibus (in French).

Wikipedia. 2015a. Horsebus. Available from Internet: http:// en.wikipedia.org/wiki/horsebus

Wikipedia. 2015b. Horsecar. http://en.wikipedia.org/wiki/horsecar

Wikipedia. 2015c. Straßenbahn Kopenhagen. Available from Internet: https://de.wikipedia.org/wiki/Stra\%C3\%9Fenbahn Kopenhagen (in German).

Wilnoteka. 2015. Available from Internet: http://www.wilnoteka.lt/pl/artykul/wilno-mma-klawo-czyli-rzecz-o-komunikacji-miejskiej-1

Žičkus, R. 2014a. Kaip Vilniuje atsirado pirmieji autobusai. Available from Internet: http://www.delfi.lt/auto/laisva-pavara/ kaip-vilniuje-atsirado-pirmieji-autobusai.d?id=66526172 (in Lithuanian).

Žičkus, R. 2014b. Lietuvos verslininkų imlumo naujovems pavyzdys: kaip mūsu krašte atsirado pirmieji autobusai. Available from Internet: http://www.delfi.lt/auto/laisva-pavara/ lietuvos-verslininku-imlumo-naujovems-pavyzdys-kaipmusu-kraste-atsirado-pirmieji-autobusai.d?id=63866576 (in Lithuanian). 